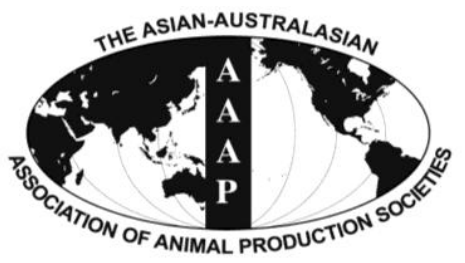

Asian-Aust. J. Anim. Sci.

Vol. 25, No. 4 : 569 - 576

April 2012

www.ajas.info

http://dx.doi.org/10.5713/ajas.2011.11425

\title{
Forsythia suspensa Extract Has the Potential to Substitute Antibiotic in Broiler Chicken
}

\author{
X. Han, X. S. Piao*, H. Y. Zhang, P. F. Li, J. Q. Yi, Q. Zhang and P. Li \\ State Key Laboratory of Animal Nutrition, Ministry of Agriculture Feed Industry Centre, \\ China Agricultural University, Beijing 100193, China
}

\begin{abstract}
Two experiments were conducted to investigate the potential for Forsythia suspensa extract (FSE) to substitute for antibiotic in broiler chicken. First, a well-diffusion assay procedure and a 2-fold dilution method were used to determine the bacteriostatic activity of FSE on Escherichia coli K88, staphylococcus aureus, and salmonella was assayed. An inhibitory effect of FSE was observed on the growth of these bacteria. This effect seems to be dose depended, which disappeared after $25.00,12.50,1.56 \mathrm{mg} / \mathrm{ml}$. Second, a 42-d trial with 252 broiler chickens (d 1, 38.7 $\pm 1.1 \mathrm{~g} \mathrm{BW}$ ) was conducted to evaluate the effect of dietary supplementation of FSE in broiler chicken. The feeding program consisted of a starter diet from d 1 to 21 and a finisher diet from d 22 to 42 . Dietary treatments included were: i) NC: negative control fed a corn-soybean meal based diet; ii) PC: positive control group fed based diet with chlortetracycline; and iii) FC: a test group fed with $100 \mathrm{mg}$ FSE/kg diet. In this study growth performance did not differ among treatments during the starter period. However, dietary supplemental chlortetracycline and FSE increased $(p<0.05)$ average daily gain (ADG), average daily feed intake (ADFI) compared with NC during the finisher and overall phase. Apparent digestibility of calcium on $\mathrm{d} 21$, digestibility of energy and calcium on $\mathrm{d} 42$ of FC was greater $(\mathrm{p}<0.05)$ than NC. Moreover, cecal Escherichia coli counts for birds from FC were lower $(\mathrm{p}<0.05)$ than NC. Dietary FSE supplementation also improved $(\mathrm{p}<0.05)$ villus height and villus height to crypt depth ratios in both duodenum and ileum and decreased $(\mathrm{p}<0.05)$ crypt depth in the duodenum. Duodenum villus height and villus height to crypt depth ratio in both duodenum and ileum from the FC group were also greater $(\mathrm{p}<0.05)$. Serum growth hormone and IGF-1 were not influenced by different treatments. Apparently, FSE has the potential to substitute for antibiotic in broiler chicken. (Key Words : Antibiotic, Broiler, Forsythia Suspensa, Performance)
\end{abstract}

\section{INTRODUCTION}

Subtherapeutic use of antibiotics has widely been applied to maintain livestock health and improve growth performance (Lien et al., 2007). However, issues with the development of bacterial resistance make the subtherapeutic use of antibiotics seem to be a double edged sword (Cassel, 1995; Bach Knudsen, 2001; Smith et al., 2002). Their use for therapeutic and growth improvement purposes at least in Europe have been forbidden. Therefore, substitutes for antibiotic with high efficiency and low toxicity are required.

Many Chinese herbal medicines such as Coptidis rhizome and Phelodendri cortex have been used to treat patients with gastroenteritis, inflammation, diarrhea, gout, and hyperuricemia which are related to the effect of

\footnotetext{
* Corresponding Author : X. S. Piao. Tel : +86-10-62733588, Fax : +86-10-62733688, E-mail : piaoxsh@mafic.ac.cn Submitted Nov. 14, 2011; Accepted Jan. 4, 2012; Revised Jan. 17, 2012
}

antibiotics (Zhou and Mineshita., 2000; Kong et al., 2004; Shen et al., 2010).

Forsythia suspensa Vahl (Oleaceae) (FSE) is a climbing plant widely distributed in China, Japan and Korea. The extracts of the dried fruits have been used for a long time as traditional Asian medicines to treat gonorrhea, erysipedas, inflammation and pharyngitis (Piao et al., 2008a). The major active components of $F$. suspensa extract are identified as phenethyl alcohol glycoside, lignan, pentacyclic triterpenoids and volatile oil (Zhang, 2000). FSE was reported to exhibit potential antibacterial (Niu et al., 2002; Li et al., 2007; Liu et al., 2007), antiviral (Liu et al., 2004), and anti-inflammatory (Hu et al., 2007) properties. In the recent years, its antioxidant activity has been also intensively investigated (Schinella et al., 2002; Qu et al., 2008; Piao et al., 2008a; Wang et al., 2008; Piao et al., 2009). New monoepoxylignans forsythialan A, forsythialan B and another two known components (phillygenin and 8-hydroxypinoresinol), extracted from 
F. suspensa fruit, also showed their protective effects against peroxynitrite-induced oxidative stress in LLC-PK cells (Piao et al., 2008a). In addition, FSE could reduce oxidative stress for broiler chickens and rats (Wang et al., 2008; Lu et al., 2010). In a word, it is reasonable to conclude that FSE has the potential to be a substitute for antibiotics to maintain livestock health and improve their growth performance.

Under farming conditions, Escherichia coli, salmonella, and Staphylococcus aureus are three of the most harmful bacteria for broiler chickens (Chinivasagam et al., 2009; Revolledo and Ferreira, 2010). Therefore, we evaluated the bacteriostatic activities of $F$. suspensa extract on Escherichia coli K88, staphylococcus aureus, and salmonella in vitro, an animal experiment was also conducted to evaluate the effect of FSE as a substitute for antibiotic.

\section{MATERIALS AND METHODS}

\section{Extracts preparation from Forsythia suspensa}

Forsythia suspensa extract was prepared using the method described by Wang et al. (2008). Dried fruits of Forsythia suspensa were purchased from Tong Ren Tang (Beijing, China; collected from Shanxi province, August). In brief, dried fruits of Forsythia suspensa were ground to powder $(100 \mathrm{~g})$, extracted with $500 \mathrm{ml}$ of $80 \%$ methanol, sonicated for $3 \mathrm{~h}$, filtered, and extracted twice $(500 \mathrm{ml}$ each time). The filtrates were combined, and dried by rotary vaporization (Büchi, Rotavapor R-124, Flawil, Switzerland).

\section{Bacteriostatic activities of Forsythia suspense extract in vitro}

Escherichia coli K88, Staphylococcus aureus, and Salmonella enteric 34R99 were purchased from the China Veterinary Culture Collection Center (Beijing, China). The strains were kept at $-70^{\circ} \mathrm{C}$ in $\mathrm{LB}$ agar, activated by transferring into nutritive agar, and incubating at $37 \pm 1.0^{\circ} \mathrm{C}$ for $18 \mathrm{~h}$.

A well-diffusion assay procedure and a 2-fold dilution method were used to assay the bacteriostatic activity of FSE (Dimov, 2007; Lima et al., 2008). Briefly, Forsythia suspensa extract from each serial dilution was placed into 5 -mm wells of the plates seeded with the bioassay strain. After $18 \mathrm{~h}$ of incubation at $37^{\circ} \mathrm{C}$, clear zones of inhibition appeared where the strain was sensitive. The diameter of these zones was then measured using a vernier caliper. Diameter beyond $8.0 \mathrm{~mm}$ was considered as sensitive inhibition (Yang et al., 2009). Media for Escherichia coli K88 and Staphylococcus aureus were extract broth (beef extract, $3 \mathrm{~g}$; peptone, $10 \mathrm{~g}$; NaCl, $5 \mathrm{~g}$; agar, 15 to $18 \mathrm{~g}$;

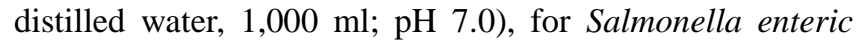

BPY agar media (beef extract, $5 \mathrm{~g}$; peptone, $10 \mathrm{~g}$; yeast extract, $5 \mathrm{~g}$; glucose, $5 \mathrm{~g}$; $\mathrm{NaCl}, 5 \mathrm{~g}$; agar, $15 \mathrm{~g}$; distilled water, $1,000 \mathrm{ml}$; $\mathrm{pH} 7.0$ ) was used.

\section{Experimental animals}

A total of 252 male broiler chickens $(38.7 \pm 1.1 \mathrm{~g}$, Arbor Acres, $1 \mathrm{~d}$ old) were used in this study. There were 14 cages per treatment for replication and 6 birds per cage. All birds were housed in wire-floored cages in an environmentally controlled room with continuous light. The lighting regimen and ventilation were continuously monitored from d 1 to 42 . The birds had access to feed and water ad libitum. During the experimental period, relative humidity was $44 \pm 6 \%$. The room temperature was maintained at $33^{\circ} \mathrm{C}$ for the first $3 \mathrm{~d}$, after which the temperature was gradually reduced to $24^{\circ} \mathrm{C}$; which was maintained during the $42 \mathrm{~d}$ experiment period. All birds were inoculated with inactivated infectious bursa disease vaccine on $\mathrm{d} 14$ and 21 and with Newcastle disease vaccine on $\mathrm{d} 7$ and 28 . The trial was conducted in 2 phases consisting of a starter phase from $\mathrm{d} 1$ to 21 and a finisher phase from d 22 to 42 . The animal care protocol in this experiment was approved by the Animal Welfare Committee of China Agricultural University.

\section{Experimental design and diets}

The broilers were randomly allotted to 3 dietary treatments (Table 1) including i) NC: a negative control group fed with a corn-soybean meal based diet without chlortetracycline and FSE; ii) PC: a positive control group fed a diet with $80 \mathrm{mg}$ chlortetracycline/ $\mathrm{kg}$ diet during 1 to $21 \mathrm{~d}$, and $50 \mathrm{mg} / \mathrm{kg}$ during 22 to $42 \mathrm{~d}$; iii) FC: a test group fed with $100 \mathrm{mg}$ FSE/kg diet. There were 14 cages per treatment with 6 birds per cage. All essential nutrients contained in the basal diet (Table 1) met or exceeded nutrient requirements suggestion from NRC (2004). All diets were fed in a mash form.

\section{Sampling and sample processing procedure}

The excreta from each cage were collected from d 19 to 21 and from d 40 to 42 , weighed, and dried at $60^{\circ} \mathrm{C}$ for $72 \mathrm{~h}$. The feed and dried excreta samples were ground to pass through a 40-mesh screen and mixed thoroughly before analysis. The DM, CP, calcium, and phosphorus contents were determined according to AOAC (2000), and gross energy content was measured by an adiabatic bomb calorimeter (Model 1281, Parr, Moline, IL, USA) to calculate $\mathrm{CP}$ retention and apparent nutrient digestibility.

On d 21 and 42, body weight (BW) and feed intake (FI) were measured after $12 \mathrm{~h}$ fasting to determine average daily gain (ADG), average daily feed intake (ADFI), and feed conversion ratio (FCR). One bird per cage was randomly selected and euthanized for sampling. Blood was collected 
Table 1. Composition of basal diets and nutrient levels ${ }^{1}$

\begin{tabular}{|c|c|c|}
\hline Items & $\begin{array}{l}\text { Starter phase } \\
\quad(1-21 \mathrm{~d})\end{array}$ & $\begin{array}{l}\text { Finisher phase } \\
\quad(22-42 \mathrm{~d})\end{array}$ \\
\hline \multicolumn{3}{|l|}{ Ingredients $(\%)$} \\
\hline Corn & 55.62 & 60.99 \\
\hline Soybean meal, $44 \%$ crude protein & 32.20 & 26.83 \\
\hline Fish meal, $64 \%$ crude protein & 4.00 & 4.00 \\
\hline Soybean oil & 3.86 & 4.33 \\
\hline Limestone & 1.27 & 1.18 \\
\hline Dicalcium phosphate & 1.31 & 1.08 \\
\hline Salt & 0.35 & 0.35 \\
\hline Premix $^{2}$ & 1.00 & 1.00 \\
\hline L-lysine $\cdot \mathrm{HCl}, 78 \%$ & 0.11 & 0.09 \\
\hline DL-methionine, $98 \%$ & 0.28 & 0.15 \\
\hline Total & 100.00 & 100.00 \\
\hline \multicolumn{3}{|l|}{ Nutrient levels } \\
\hline Metabolic energy (kcal/g) & 3.00 & 3.10 \\
\hline Crude protein $(\%)$ & 21.50 & 19.50 \\
\hline Calcium (\%) & 1.00 & 0.90 \\
\hline Available phosphorus (\%) & 0.45 & 0.40 \\
\hline Lysine $(\%)$ & 1.30 & 1.15 \\
\hline Methionine (\%) & 0.65 & 0.50 \\
\hline \multicolumn{3}{|l|}{ Analyzed composition } \\
\hline Crude protein $(\%)$ & 21.56 & 19.51 \\
\hline Calcium $(\%)$ & 1.01 & 0.88 \\
\hline Phosphorus (\%) & 0.68 & 0.58 \\
\hline Lysine (\%) & 1.33 & 1.14 \\
\hline Methionine (\%) & 0.66 & 0.52 \\
\hline
\end{tabular}

${ }^{1}$ The basal pretreatment diet and treatment diets were the same. Treatment diets were supplemented with $100 \mathrm{mg} / \mathrm{kg}$ Forsythia suspensa extract, or chlortetracycline $(80 \mathrm{mg} / \mathrm{kg}$ for the starter birds and $50 \mathrm{mg} / \mathrm{kg}$ for the finisher birds) to the basal diet as part of the premix.

2 The premix provided the following per kilogram of compound feed: zinc, $60 \mathrm{mg}$; iron, $95 \mathrm{mg}$; manganese, $80 \mathrm{mg}$; copper, $10 \mathrm{mg}$; iodine, 0.35 mg; selenium, $0.3 \mathrm{mg}$; vitamin A, 10,000 IU; vitamin $\mathrm{D}_{3}, 2,750 \mathrm{IU}$; vitamin $\mathrm{E}, 30 \mathrm{IU}$; vitamin $\mathrm{K}_{3}, 2 \mathrm{mg}$; vitamin $\mathrm{B}_{12}, 12 \mu \mathrm{g}$; riboflavin, $6 \mathrm{mg}$; nicotinic acid, $40 \mathrm{mg}$; pantothenic acid, $12 \mathrm{mg}$; pyridoxine, $3 \mathrm{mg}$; biotin, $0.2 \mathrm{mg}$; choline chloride, $800 \mathrm{mg}$.

$(5 \mathrm{ml})$ by cardiac puncture using a $10-\mathrm{ml}$ anticoagulant-free vacutainer tube (Greiner Bio-One $\mathrm{GmbH}$, Kremsmunster, Austria), centrifuged at $3,000 \times \mathrm{g}$ for $10 \mathrm{~min}$ to obtain the serum, and stored at $-80^{\circ} \mathrm{C}$ until analysis for growth hormone $(\mathrm{GH})$ and insulin-like growth factor 1 (IGF-1). Samples of digesta $(5 \mathrm{ml})$ from the cecum were obtained, and stored at $-80^{\circ} \mathrm{C}$ until microbial counting. On d 42 , about $5 \mathrm{~cm}$ segments of duodenum, jejunum, and ileum were removed and immediately flushed with ice-cold $0.9 \%$ saline solution to remove any excess blood and digesta. Tissues were then fixed with $10 \%$ formaldehyde-phosphate buffer, and kept at $4{ }^{\circ} \mathrm{C}$ until microscopic assessments of mucosa morphology.

\section{Assay of serum GH and IGF-1}

Serum GH level was determined using a radioimmunoassay kit (Beijing Siano-uk Institute of Biological Technology, Beijing) (Li et al., 2007). Variation between or within groups was less than $13 \%$ and $9.0 \%$, respectively. Recovery was from $95 \%$ to $104 \%$. Serum IGF-1 level was also determined using the radioimmunoassay kit (Diagnostic System Laboratories Inc., America). Variation between or within groups was less than $8.2 \%$ and $3.4 \%$, respectively. Recovery was from $89 \%$ to $122 \%$.

\section{Microbial counting}

Microbial analysis was carried out according to the procedure introduced by Shen et al. (2009). Escherichia coli were cultured in MacConkey agar (Beijing Haidian Microbiological Culture Factory, Beijing, China). Lactobacillus was determined using MRS agar (Beijing Haidian Microbiological Culture Factory, Beijing, China). Data between 30 to 300 were available. Results were expressed as $\log _{10}$ cfu per gram.

\section{Statistical analysis}

Data were subjected to ANOVA using the GLM procedure of SAS (SAS Institute, 1996). Cage was the experimental unit. Differences among treatments were separated by Duncan's multiple range tests. Probability values less than 0.05 were considered significant.

\section{RESULTS}

\section{Bacteriostatic activities of Forsythia suspense extract in vitro}

Bacteriostatic activities of FSE on all three bacteria were observed (Figure 1). The inhibition effect on the growth of these bacteria seems to be dose depended. In this serial dilution method based experiment, the inhibitory effect of FSE on Escherichia coli K88, Staphylococcus aureus, and Salmonella 34R99 disappeared after 25.00, $12.50,1.56 \mathrm{mg} / \mathrm{ml}$, respectively (Table 2 ).

\section{Growth performance}

In the starter phase, no treatment effect of FSE or chlortetracycline on ADG, ADFI, and FCR of broiler chickens was observed (Table 3). In the finisher phase, $\mathrm{ADG}$ of FC and PC was greater (16.2\% and $12.2 \%$ respectively, $\mathrm{p}<0.01$ ) than $\mathrm{NC}$, a similar effect of FSE and chlortetracycline supplementation on ADFI was also observed $(9.6 \%$ and $11.5 \%$ respectively, $\mathrm{p}<0.01)$. However, FCR was not affected by dietary treatment. No difference between PC and FSE was observed on ADG, ADFI, and FCR of broiler chickens. For the entire period, dietary supplementation with FSE and chlortetracycline improved 

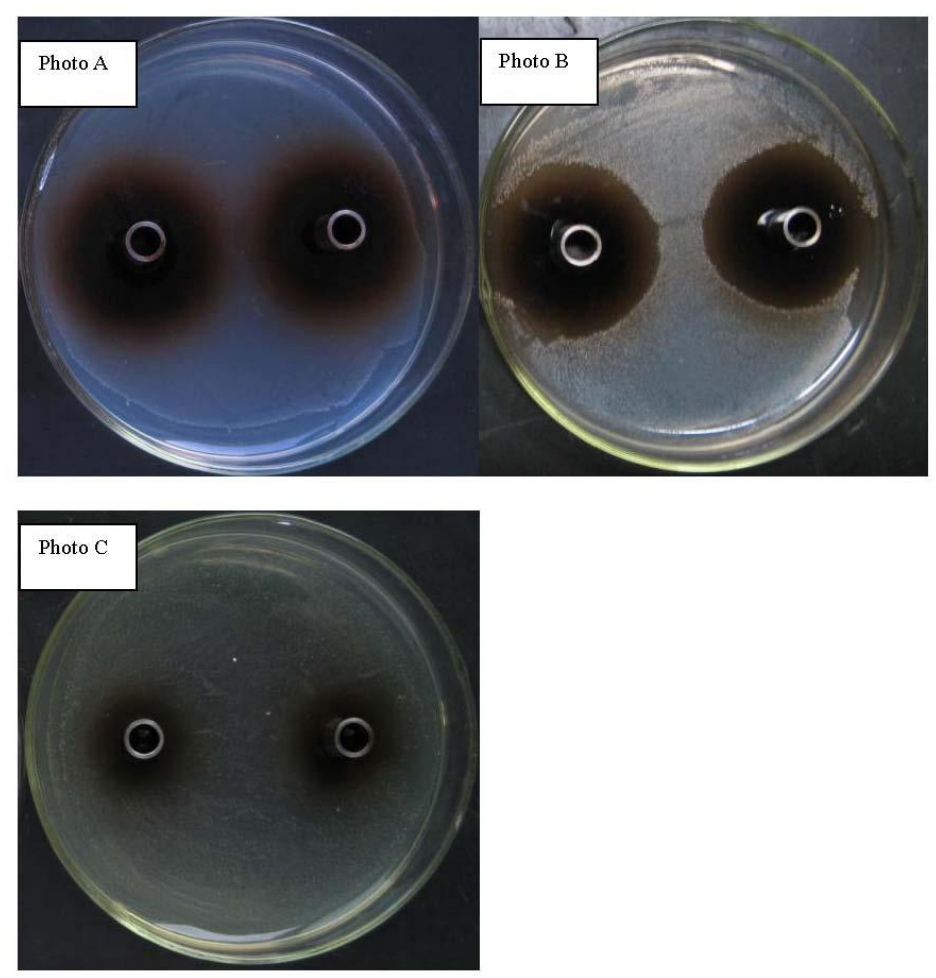

Figure 1. Photo of bacteriostatic activities of Forsythia suspensa extract on the Escherichia coli K88, Staphylococcus aureus, and Salmonella. Concentration of FSE was $200 \mathrm{mg} / \mathrm{ml}$, photo A was for Escherichia coli K88, photo B was for Staphylococcus aureus, photo C was for Salmonella.

Table 2. Bacteriostatic circle diameter of Forsythia suspensa extract on the Escherichia coli K88, Staphylococcus aureus, and Salmonella

\begin{tabular}{|c|c|c|c|c|c|c|c|c|c|c|}
\hline \multirow{2}{*}{ Items } & \multicolumn{10}{|c|}{ Two-fold dilution } \\
\hline & $1: 1$ & $1: 2$ & $1: 4$ & $1: 8$ & $1: 16$ & $1: 32$ & $1: 64$ & $1: 128$ & $1: 256$ & $1: 512$ \\
\hline $\begin{array}{l}\text { Bacteriostatic circle diameter of } \\
\text { Staphylococcus aureus }(\mathrm{mm})\end{array}$ & 38.00 & 32.63 & 32.50 & 29.67 & 27.50 & 23.67 & 13.17 & 10.33 & & \\
\hline $\begin{array}{l}\text { Bacteriostatic circle diameter of } \\
\text { Escherichia coli } \mathrm{K} 88(\mathrm{~mm})\end{array}$ & 16.50 & 13.25 & 10.83 & 8.17 & & & & & & \\
\hline $\begin{array}{l}\text { Bacteriostatic circle diameter of } \\
\text { Salmonella }(\mathrm{mm})\end{array}$ & 22.25 & 19.88 & 14.17 & 11.33 & 9.12 & & & & & \\
\hline
\end{tabular}

Table 3. Effects of dietary FSE and chlortetracycline supplement on the growth performance in broilers

\begin{tabular}{|c|c|c|c|c|c|}
\hline \multirow{2}{*}{ Items } & \multicolumn{3}{|c|}{ Treatments } & \multirow{2}{*}{ SEM } & \multirow{2}{*}{$\mathrm{p}$ value } \\
\hline & $\mathrm{NC}$ & FC & PC & & \\
\hline \multicolumn{6}{|l|}{$\overline{\mathrm{ADG}(\mathrm{g})}$} \\
\hline $1-21 \mathrm{~d}$ & 32 & 34 & 33 & 0.01 & 0.44 \\
\hline $22-42 d$ & $67^{\mathrm{b}}$ & $78^{\mathrm{a}}$ & $75^{\mathrm{a}}$ & 1.57 & $<0.01$ \\
\hline $1-42 \mathrm{~d}$ & $50^{\mathrm{b}}$ & $56^{\mathrm{a}}$ & $54^{\mathrm{a}}$ & 1.15 & $<0.01$ \\
\hline \multicolumn{6}{|l|}{ ADFI (g) } \\
\hline $1-21 \mathrm{~d}$ & 45 & 46 & 45 & 0.34 & 0.59 \\
\hline $22-42 d$ & $124^{\mathrm{b}}$ & $136^{\mathrm{a}}$ & $138^{\mathrm{a}}$ & 2.15 & $<0.01$ \\
\hline $1-42 \mathrm{~d}$ & $85^{\mathrm{b}}$ & $91^{\mathrm{a}}$ & $92^{\mathrm{a}}$ & 0.85 & $<0.01$ \\
\hline \multicolumn{6}{|l|}{ FCR } \\
\hline $1-21 \mathrm{~d}$ & 1.40 & 1.36 & 1.37 & 0.01 & 0.66 \\
\hline $22-42 d$ & 1.86 & 1.75 & 1.84 & 0.03 & 0.19 \\
\hline $1-42 \mathrm{~d}$ & 1.71 & 1.64 & 1.71 & 0.02 & 0.17 \\
\hline
\end{tabular}

${ }^{\mathrm{a}, \mathrm{b}}$ Means within a row with different letter differ $(\mathrm{p}<0.05)$; SEM is standard error of the mean. 
Table 4. Effects of dietary Forsythia suspensa extract (FSE) supplement on the apparent digestibility (\%) of nutrients and bacterial concentrations $(\log \mathrm{CFU} / \mathrm{g}$ wet digesta) in broilers

\begin{tabular}{|c|c|c|c|c|c|}
\hline \multirow{2}{*}{ Items } & \multicolumn{3}{|c|}{ Treatments } & \multirow{2}{*}{ SEM } & \multirow{2}{*}{$\mathrm{p}$ value } \\
\hline & $\mathrm{NC}$ & $\mathrm{FC}$ & $\mathrm{PC}$ & & \\
\hline \multicolumn{6}{|l|}{$\mathrm{d} 21$} \\
\hline Dry matter & 71.32 & 72.53 & 72.41 & 0.51 & 0.80 \\
\hline Energy & 78.32 & 76.18 & 77.48 & 0.45 & 0.18 \\
\hline Crude protein & 69.60 & 68.01 & 69.12 & 0.82 & 0.74 \\
\hline Calcium & $51.31^{\mathrm{b}}$ & $58.72^{\mathrm{a}}$ & $55.24^{\mathrm{ab}}$ & 1.76 & $<0.05$ \\
\hline Phosphorus & 53.95 & 55.85 & 56.24 & 1.31 & 0.77 \\
\hline Lactobacillus & 5.47 & 5.48 & 5.57 & 0.11 & 0.45 \\
\hline Escherichia coli & $6.74^{\mathrm{a}}$ & $5.85^{\mathrm{b}}$ & $5.58^{\mathrm{b}}$ & 0.15 & $<0.05$ \\
\hline \multicolumn{6}{|l|}{$\mathrm{d} 42$} \\
\hline Dry matter & 72.16 & 73.31 & 73.25 & 0.57 & 0.85 \\
\hline Energy & $77.53^{\mathrm{b}}$ & $80.52^{\mathrm{a}}$ & $79.40^{\mathrm{ab}}$ & 0.49 & $<0.05$ \\
\hline Crude protein & 60.06 & 63.25 & 60.07 & 0.93 & 0.28 \\
\hline Calcium & $46.47^{\mathrm{b}}$ & $62.12^{\mathrm{a}}$ & $52.97^{\mathrm{b}}$ & 2.15 & $<0.05$ \\
\hline Phosphorus & 46.23 & 53.53 & 53.17 & 1.73 & 0.15 \\
\hline Lactobacillus & 7.12 & 7.44 & 7.42 & 0.09 & 0.56 \\
\hline Escherichia coli & $6.19^{\mathrm{a}}$ & $5.41^{\mathrm{b}}$ & $5.31^{\mathrm{b}}$ & 0.12 & $<0.05$ \\
\hline
\end{tabular}

ADG (12.4\% and $8.6 \%$ respectively, $\mathrm{p}<0.01)$ and ADFI ( $7.9 \%$ and $8.4 \%$ respectively, $\mathrm{p}<0.01)$ compared with $\mathrm{NC}$, FCR was still not affected by dietary treatment.

\section{Apparent digestibility}

At the end of starter phase, the apparent digestibility of calcium was improved $(14.4 \%, \mathrm{p}<0.05)$ by FSE supplementation compared with NC (Table 4), no dietary treatment effect was observed on the apparent digestibility of DM, energy, CP, and phosphorus. At the end of finisher phase, the apparent digestibility of energy $(p<0.05)$ and calcium $(\mathrm{p}<0.05)$ were improved by FSE and chlortetracycline supplementation compared with NC. No difference between FC and PC was observed.

\section{Histological measurements}

As determined at d 42, dietary FSE supplementation improved $(\mathrm{p}<0.05)$ villus height and villus height to crypt depth ratios in both duodenum and ileum, decreased $(\mathrm{p}<0.05)$ crypt depth in duodenum compared with $\mathrm{NC}$ (Table 5). Duodenum villus height and villus height to crypt depth ratios in both duodenum and ileum from FC were also greater $(\mathrm{p}<0.05)$ than PC. In jejunum, similar effects were also observed but not significantly.

\section{Cecum microflora and serum GH and IGF-1}

No effect of dietary treatment on cecum lactobacilli counts was observed on d 21 or d 42 for broiler chicken. Both FSE and chlortetracycline supplementation decreased $(\mathrm{p}<0.05)$ cecum $E$. coli counts on d 21 and d 42 compared

Table 5. Effects of dietary Forsythia suspensa extract (FSE) supplement on small intestinal morphology in broilers

\begin{tabular}{|c|c|c|c|c|c|}
\hline \multirow{2}{*}{ Items } & \multicolumn{3}{|c|}{ Treatments } & \multirow{2}{*}{ SEM } & \multirow{2}{*}{$\mathrm{p}$ value } \\
\hline & $\mathrm{NC}$ & FC & $\mathrm{PC}$ & & \\
\hline \multicolumn{6}{|c|}{ Villus height $(\mu \mathrm{M})$} \\
\hline Duodenum & $1,198.7^{\mathrm{b}}$ & $1,379.7^{\mathrm{a}}$ & $1,199.0^{\mathrm{b}}$ & 34.11 & 0.03 \\
\hline Jejunum & 579.6 & 631.8 & 601.6 & 19.62 & 0.58 \\
\hline Ileum & $473.8^{\mathrm{b}}$ & $609.0^{\mathrm{a}}$ & $547.6^{\mathrm{ab}}$ & 20.73 & $<0.05$ \\
\hline \multicolumn{6}{|c|}{ Crept depth $(\mu \mathrm{M})$} \\
\hline Duodenum & 203.4 & $163.9^{\mathrm{b}}$ & $192.4^{\mathrm{ab}}$ & 6.81 & $<0.05$ \\
\hline Jejunum & 178.4 & 167.9 & 160.8 & 5.72 & 0.47 \\
\hline Ileum & 161.0 & 139.7 & 164.6 & 5.53 & 0.13 \\
\hline \multicolumn{6}{|c|}{ Villus height/crept depth ratio } \\
\hline Duodenum & $6.00^{\mathrm{b}}$ & $8.67^{\mathrm{a}}$ & $6.27^{\mathrm{b}}$ & 0.42 & $<0.01$ \\
\hline Jejunum & 3.26 & 3.76 & 3.74 & 0.22 & 0.43 \\
\hline Ileum & $2.99^{\mathrm{b}}$ & $4.44^{\mathrm{a}}$ & $3.40^{\mathrm{b}}$ & 0.23 & $<0.05$ \\
\hline
\end{tabular}


Table 6. Effects of dietary Forsythia suspensa extract (FSE) supplement on serum growth hormone and IGF- I concentrations $(\mathrm{ng} / \mathrm{ml})$ in broilers

\begin{tabular}{cccccc}
\hline \multirow{2}{*}{ Items } & \multicolumn{3}{c}{ Treatments } & \multirow{2}{*}{ SEM } & p value \\
\cline { 2 - 4 } & $\mathrm{NC}$ & $\mathrm{FC}$ & $\mathrm{PC}$ & & \\
\hline Growth hormone & $(\mathrm{ng} / \mathrm{ml})$ \\
d 21 & 6.20 & 6.27 & 5.85 & 0.39 & 0.91 \\
d 42 & 4.24 & 5.01 & 4.19 & 3.63 & 0.63 \\
Insulin-like growth factor-I (ng/ml) & & & \\
d 21 & 209.63 & 209.04 & 217.22 & 0.37 & 0.61 \\
d 42 & 206.31 & 228.48 & 180.66 & 9.48 & 0.12 \\
\hline
\end{tabular}

with NC group (Table 4). No effect of dietary treatment on serum GH concentration or IGF-I concentration was observed during the experimental period $(\mathrm{p}>0.05)$ (Table 6).

\section{DISCUSSION}

The bacteria selected in this study were three of the most dangerous bacteria to the poultry industry. Escherichia coli has several virulence attributes which result in variety of diseases in poultry, including salpingities, sinovities, omphalitis, and chronic respiratory disease (Gutierrez et al., 2010). These virulence attributes could promote colonization or adhesion to the mucosa, cause metabolic dysfunction or death of enterocytes, affect the local or systemic vasculature; they promote invasion and septicemia (Jubb et al., 1993). Salmonella infection is another major problem in poultry production. The infections can sometimes lead from moderate illness all the way to death at high frequencies especially for young poultry (Gast and Holt, 1998; Oh et al., 2010). Staphylococcus aureus is also an important human and veterinary pathogen that causes great economic loss in the poultry industry. The diseases associated with this bacterium vary in severity from superficial skin and ophthalmic infections to lifethreatening endocardities, septic arthritis, and septicemia. The inhibition of FSE in vitro provided evidence for the positive effect of dietary supplemental FSE. These results of the bacteriostatic activities for FSE were consistent with previous literature (Niu et al., 2002; Li et al., 2007; Liu et al., 2007). The functioning component, forsythiaside, which was isolated from FSE, has been reported to inhibit growth of Escherichia coli-10B, Pseudomonas aeruginosa and Staphylococcus aureus-Rn4220 (Qu et al., 2008), but research on the other bacteriostatic activities is rare because of the great difficulty in purifying single components from FSE. The mechanism for such an effect is still unreported. However, the effect of dietary supplementation with FSE on maintaining health and promoting growth can be ascribed to such bacteriostatic activities.

Unlike antibiotics, FSE has also been reported to be an antioxidant. Phenylethanoid glycosides like forsythoside A, forsythoside B, and lignans such as phillyrin, forsythialan A, forsythialan B, phillygenin, and 8-hydroxypinoresinol were reported as antioxidant components of FSE (Piao et al., 2008a ; Qu et al., 2008). Protective effects of FSE against oxidative stress either peroxynitrite-induced in LLC-PK1 cells or diquat-induced in rats, and high ambient temperature induced in broiler chicken were also reported (Piao et al., 2008a; Wang et al., 2008; Lu et al., 2010). Oxidative stress is related to a number of aging-dependent pathogenic processed including cancers, arteriosclerosis, arthritis, neurodegenerative disorders and other diseases (Valko et al., 2006). At the same time, FSE was also reported to alleviate the hypersensitivity reaction induced by soybean $\beta$-conglycinin in a swine model (Hao et al., 2010). Such an effect of FSE played an important role in achieving the better intestine histological morphology compared with $\mathrm{PC}$ and $\mathrm{NC}$ in this experiment, by the way of both benefiting the repair of epidermis damage caused by pathogen and antigen protein in diet and by reducing the presence of these harmful factors. The improvement in gut health could theoretically increase the digestibility of nutrients, which was also detected in our experiment.

Unexpectedly, the effect of FSE and chlortetracycline supplementation on the growth performance and nutrient digestibility was not observed in the starter phase in this experiment. A possible reason for this result may due to the way that broiler chicks grow. About $70 \%$ of body weight is gained in the finisher phase, which is to say growth performance is easier to be influenced in broiler chickens during the finisher phase (Wang et al., 2008). Also, developments of broiler chicken in the starter phase were mainly focused on the growth from hatching of organs such as pancreas, small intestine and liver (Nitsan et al., 1991). The positive effect was expressed until the end of the finisher phase.

IGF-1 could enhance rates of net $\mathrm{Na}+$ and $\mathrm{Na}+-$ dependent nutrient absorption and stimulate electrolyte transport in animals (Alexander and Carey, 1999). It is also well established that IGF-I can influence gastrointestinal growth in adults, Intravenous or subcutaneous administration of IGF-I in adults increases intestinal mucosal weight, protein and DNA content, villus height, and epithelial proliferation (Lemmey et al., 1991; Peterson et al., 1997). GH was an important hormone which can affect growth of chickens directly (Burke et al., 1982). Effect of FSE and chlortetracycline supplementation on these hormones seems to be variable, which may exclude the possible mechanism of FSE to function in such a way.

Considering the bacteriostatic activities of FSE both in vitro and vivo, as well as its positive effect on the growth performance and histological morphology in broiler chicken, FSE has the potential to be a substitute for antibiotic. 
Further research on the functional mechanism, optimum dose in diets, methods of lowering production cost needs to be done; followed by evaluating its effect in large populations in commercial production before FSE can be used by industry.

\section{ACKNOWLEDGEMENTS}

This study was completed at the State Key Laboratory of Animal Nutrition (2004DA125184-0810) of China. The authors thank their effort to make the experiment get finished successfully.

Acknowledgement: financial supported by the National Natural Science Foundation of China (No. 31072040), State Key Laboratory of Animal Nutrition of China (No. 2004DA125184-0810), Ministry of Science and Technology of China (No. nyhyzx07-034), and Guangdong cooperation project between Industry-Academia-Research of China (No. 2009B090300110).

\section{REFERENCES}

Alexander, A. N. and H. V. Carey. 1999. Oral IGF-I enhances nutrient and electrolyte absorption in neonatal piglet intestine. Am. J. Physiol. Gastrointest. Liver Physiol. 277:619-625.

AOAC. 2000. Official methods of analysis, 17th edn. Association of Official Analytical Chemists, Arlington. Virginia, USA.

Barton, M. D. 2000. Antibiotic use in animal feed and its impact on human health. Nutr. Res. Rev. 13:279-299.

Bach Knudsen, K. E. 2001. Development of antibiotic resistance and options to replace antimicrobials in animal diets. Proc. Nutr. Soc. 60:291-299.

Burke, W. H. and H. L. Marks. 1982. Growth hormone and prolactin levels in non selected and selected broiler lines of chickens from hatch to eight weeks of age. Growth 46:283-295.

Cassel, G. H. 1995. ASM task force urges broad program on antimicrobial resistance. ASM News 61:116-120.

Chinivasagam, H. N., T. Tran, L. Maddock, A. Gale and P. J. Blackall. 2009. Mechanically ventilated broiler sheds: a possible source of aerosolized salmonella, Campylobacter, and Escherichia coli. Appl. Environ. Microbiol. 75:7417-7425.

Dimov, S. G. 2007. A novel bacteriocin-like substance produced by Enterococcus faecium 3587. Curr. Microbiol. 55:323-327.

Gast, R. K. and P. S. Holt. 1998. Persistence of salmonella enteritidis from one day of age until maturity in experimentally infected layer chickens. Poult. Sci. 77:1759-1762.

Gutierrez, L., L. Ocampo, C. Rosario and H. Sumano. 2007. Pharmacokinetics of disodium fosfomycin in broilers and dose strategies to comply with its pharmacodynamics versus Escherichia coli. Poult. Sci. 89:2106-2115.

Hao, Y., X. S. Piao and D. F. Li. 2010. Forsythia suspensa extract alleviates hypersensitivity induced by soybean $\beta$-conglycinin in weaned piglets. J. Ethnopharmacol. 128:412-418.

Hu, J. Y., L. Lei, Y. Yu and W. L. Deng. 2007. The research of Forsythia suspensa on anti-inflammatory and relieving fever activities. Pharmacol. Clin. Chin. Mater. Med. 23:51-52.
Jubb, K., P. Kennedy and N. Palmer. 1993. Nutritional myopathy. In: Pathology of domestic animals, 4th Ed. (Ed. K. Jubb, P. Kennedy and N. Palmer). Academic Press, San Diego, California. pp. 228-242.

Kong, X., Y. Hu, R. Rui, D. Wang and X. Li. 2004. Effects of chinese herbal medicinal ingredients on peripheral lymphocyte proliferation and serum antibody titer after vaccination in chicken. Int. Immunopharmacol. 4:975-982.

Lemmey, A. B., A. A. Martin, L. C. Read, F. M. Tomas, P. C. Owens and F. J. Ballard. 1991. IGF-I and the truncated analogue des-(1-3) IGF-I enhance growth in rats after gut resection. Am. J. Physiol. 260:213-219.

Li, Z. X., X. H. Wang, J. H. Zhao, J. F. Yang and X. Wang. 2007. In vitro study of antibacterial activity of Forsythia suspensa against staphylococcus aureus and sepidermidis. Tianjin J. Traditional Chin. Med. 24:328-331.

Lien, T. F., Y. M. Horng and C. P. Wu. 2007. Feasibility of replacing antibiotic feed promoters with the Chinese traditional herbal medicine Bazhen in weaned piglets. Livest. Sci. 107:97-102.

Lima, F. L., M. A. R. de Carvalho, A. C. M. Apolônio, M. P. Bemquerer, M. M. Santoro, J. S. Oliveira, C. S. Alviano and L. M. Farias. 2008. Actinomycetemcomitin: a new bacteriocin produced by Aggregatibacter (Actinobacillus) actinomycetemcomitans. J. Ind. Microbiol Biotechnol. 35:103110.

Liu, Y. J., Z. Q. Yang, H. Xiao and L. Wen. 2004. Inhibitory effect of four kinds of extract of Chinese herbs - Forsythia on herpes simplex virus type. J. Hubei College Trad. Chin. Med. 6:36-38.

Liu, W. S., Y. X. Xu and Y. L. Zheng. 2007. Effect of the ethanol extract of Forsythia suspensa (thunb.) Vahl. on the growth curve of bacterium. J. Anhui. Agric. Sci. 35:7383-7387.

Lu, T., X. L. Piao, Q. Zhang, D. Wang, X. S. Piao and S. W. Kim. 2010. Protective effects of Forsythia suspensa extract against oxidative stress induced by diquat in rats. Food Chem. Toxicol. 48:764-770.

Nitsan, Z., G. Ben-Avraham, Z. Zoref and I. Nir. 1991. Growth and development of the digestive organs and some enzymes in broiler chicks after hatching. Br. Poult. Sci. 32:515-523.

Niu, X. H., S. C. Qiu, D. L. Di, X. L. Bai and F. Gao. 2002. The in vitro growth inhibition effect of Forsythia suspensa (thunb.) Vahi (FSV) on bacteria. Li Shizhen Med. Mater. Med. Res. 13:342-343.

Oh, J. Y., M. S. Kang, B. K. An, E. A. Song, J. H. Kwon and Y. K. Kwon. 2010. Occurrence of purulent arthritis broiler vertically infected with Salmonellla enterica serovar Enteritidis in Korea. Poult. Sci. 89:2116-2122.

Peterson, C. A., H. V. Carey, P. S. Hinton, H. C. Lo and D. M. Ney. 1997. GH elevates serum IGF-I levels but does not alter mucosal atrophy in parenterally-fed rats. Am. J. Physiol. 272:1100-1108.

Piao, X. L., M. H. Jang, J. Cui and X. S. Piao. 2008a. Lignans from the fruits of Forsythia suspensa. Bioorg. Med. Chem. Lett. 18:1980-1984.

Piao, X. L., E. J. Cho, M. H. Jang and J. Cui. 2009. Cytoprotective effect of lignans from Forsythia suspensa against peroxynitrite-induced $\mathrm{LLC}^{-\mathrm{PK}_{1}}$ cell damage. Phytother. Res. 23:938-942. 
Qu, H., Y. Zhang, Y. Wang, B. Li and W. Sun. 2008. Antioxidant and antibacterial activity of two compounds (forsythiaside and forsythin) isolated from Forsythia suspensa. J. Pharm. Pharmacol. 60:261-266.

Revolledo, L. and A. J. P. Ferreira. 2010. Salmonella antibioticmutant strains reduce fecal shedding and organ invasion in broiler chicks. Poult. Sci. 89:2130-2140.

SAS Institute. 1996. SAS user's guide: statisitcs. Version 7.0. SAS Institute, Cary, North Carolina.

Schinella, G. R., H. A. Tournier, J. M. Prieto, B. P. de Mordujovich and J. L. Rios. 2002. Antioxidant activity of anti-inflammatory plant extracts. Life Sci. 70:1023-1033.

Shen, Y. B., X. S. Piao, S. W. Kim, L. Wang, P. Liu, I. Yoon and Y. G. Zhen. 2009. Effects of yeast culture supplementation on growth performance, intestinal health, and immune response of nursery pigs. J. Anim. Sci. 87:2614-2624.

Shen, Y. B., X. S. Piao, S. W. Kim, L. Wang and P. Liu. 2010. The effects berberine on the magnitude of the acute inflammatory response induced by Escherichia coli lipopolysaccharide in broiler chickens. Poult. Sci. 89:13-19.
Smith, D. L., A. D. Harris, J. A. Johnson, E. K. Silbergeld and Jr. J. G. Morris. 2002. Animal antibiotic use has an early but important impact on the emergence of antibiotic resistance in human commensal bacteria. Proc. Natl. Acad. Sci. 99:64346439.

Valko, M., C. J. Rhodes, J. Moncol, M. Izakovic and M. Mazur. 2006. Free radicals, metals and antioxidants in oxidative stress-induced cancer. Chem. Biol. Interact. 160:1-40.

Wang, L., X. L. Piao, S. W. Kim, X. S. Piao, Y. B. Shen and H. S. Lee. 2008. Effects of forsythia suspensa extract on growth performance, nutrient digestibility, and antioxidant activities in broiler chickens under high ambient temperature. Poult. Sci. 87:1287-1294.

Yang, J., Z. H. Li, L. Huang, J. L. Li, R. Wen and P. W. Cui. 2009. Antimicrobial activity of the volatile oil from Valeriana officinalis L. Li Shizhen Med. Mater. Med. Res. 20:1651-1652.

Zhang, H. Y. 2000. The advanced research of Forsythia Suspensa on its chemical components and pharmacological activities. J. Chin. Med. Mater. 23:657-660.

Zhou, H. Y. and S. Mineshita. 2000. The effect of berberine chloride on experimental colitis in rats in vivo and in vitro. J. Pharmacol. Exp. Ther. 294:822-829. 